\title{
Research
}

\section{The correlation between earphone usage patterns with the incidence rate and severity of tinnitus}

\author{
Adrian Joshua Velaro, Devira Zahara \\ Department of Otorhinolaryngology-Head and Neck Surgery \\ Faculty of Medicine Universitas Sumatera Utara/H.Adam Malik General Hospital, Medan
}

\begin{abstract}
Background: Earphone nowadays is extensively used along with audiovisual technology development. The increased use of earphone can lead to tinnitus. Around 10-20\% of the adult population had experienced tinnitus during their life, and $0.5-2.5 \%$ affected their quality of life. Tinnitus in medical students could interfere in the teaching process which could can lead to decreased quality of medical students. Objective: To observe the correlation between the pattern of using earphone with the incidence of tinnitus, and to determine the severity of tinnitus among students of the Faculty of Medicine, Universitas Sumatera Utara, class 2017-2019 who used earphones. Method: This was an analytic study with crosssectional design, using consecutive sampling technique. Result: Bivariate analysis between earphone use patterns and the incidence of tinnitus among the subjects obtained statistically significant results $(\mathrm{p}=0.017)$. Univariate analysis on 148 respondents showed a pattern of risky earphone use $(64.2 \%)$ and 52 people with tinnitus (35.1\%), and tinnitus severity with 52 participants based on Visual Analogue Scale was mild (55.8\%) and based on Tinnitus Handicap Inventory Questionnaire was light (53.9\%). In the pattern of earphone use, the results of the analysis of the frequency of using earphones for 3-4 days were $(40.5 \%)$, the volume of earphone use was $60-80 \%(54.1 \%)$, the length of time using earphones $>3$ years was $(65.5 \%)$, and the duration of using earphones $<1$ hour $(38.5 \%)$. Conclusion: There was a correlation between the pattern of earphone use and the incidence of tinnitus among students at the Faculty of Medicine, Universitas Sumatera Utara, class 2017-2019.
\end{abstract}

Keywords: earphone, tinnitus, Visual Analog Scale, Tinnitus Handicap Inventory Questionnaire

\begin{abstract}
ABSTRAK
Latar belakang: Earphone saat ini sangat banyak digunakan seiring dengan perkembangan teknologi audiovisual. Prevalensi pengguna earphone pada remaja sekitar 83,6\% dari 436 remaja. Penggunaan earphone yang berlebihan dapat menyebabkan tinitus. Statistik prevalensi dunia menunjukkan 30-40\% populasi dewasa pernah mengalami tinnitus dalam hidupnya dan 0,5-2,5\% kualitas hidupnya sangat terganggu oleh tinitus. Tinitus merupakan salah satu tanda penurunan fungsi pendengaran dan mampu menyebabkan penurunan performa kognitif. Tinitus pada mahasiswa kedokteran dapat mengganggu proses belajar mengajar sehingga dapat menurunkan kualitas mahasiswa kedokteran. Tujuan: Untuk mengetahui apakah terdapat hubungan pola penggunaan earphone dengan angka kejadian tinnitus serta tingkat keparahan tinitus pada mahasiswa Fakultas Kedokteran Universitas Sumatera Utara. Metode: Penelitian analitik dengan desain potong lintang dengan teknik pengambilan secara consecutive sampling. Pengukuran dilakukan dengan Visual Analog Scale (VAS) dan Tinitus Handicap Inventory Questionnaire (THI-Q). Hasil: Analisis bivariat antara pola penggunaan earphone dengan angka kejadian tinnitus pada mahasiswa Fakultas Kedokteran Universitas Sumatera Utara diperoleh hasil $(p=0,017)$. Analisis univariat pada 148 responden menunjukkan pola penggunaan earphone berisiko sebanyak $(64,2 \%)$ dan yang mengidap tinitus sebanyak 52 orang $(35,1 \%)$, dan tingkat keparahan tinitus dengan jumlah responden 52 orang berdasarkan VAS adalah ringan $(55,8 \%)$ dan berdasarkan THI-Q adalah ringan (53,9\%). Pada pola penggunaan earphone diperoleh hasil analisis frekuensi penggunaan earphone 3-4 hari sebanyak (40,5\%), volume penggunaan earphone $60-80 \%$ sebanyak (54,1\%), lama penggunaan earphone $>3$ tahun sebanyak $(65,5 \%)$, dan durasi penggunaan
\end{abstract}


earphone $<1$ jam sebanyak (38,5\%). Kesimpulan: Terdapat hubungan antara pola penggunaan earphone dengan angka kejadian tinitus pada mahasiswa Fakultas Kedokteran Universitas Sumatera Utara angkatan 2017-2019.

Kata kunci: earphone, tinitus, Visual Analog Scale, Tinnitus Handicap Inventory Questionnaire

Correspondence address: Adrian Joshua Velaro. Department of OtoRhinoLaryngology-Head and Neck Surgery, Faculty of Medicine Universitas Sumatera Utara. E-mail: ajoshuav@gmail.com.

\section{INTRODUCTION}

Current improvements in audiovisual technology have had a major impact on innovations in music players and hearing devices for listening to music from music players and other audio devices. Numerous types of hearing devices have been produced with various capacities and functions of sound output, such as earphones, headsets, headphones, and others. ${ }^{1}$

One study reported that as many as $88.2 \%$ out of 1407 children used a personal music player known as MP3, and $27.4 \%$ of them listened to music at maximum volume for a long time without pause. In another study, it was also stated that out of the 490 study subjects, $94.3 \%$ of them used personal music players and almost all of them used the tool for 1-3 hours every day for three years. While the hearing device that is most widely used is the type of earphone.This shows how widespread the use of earphones in society, especially adolescents. ${ }^{2,3}$

Excessive use of earphones and for long periods of time can lead to chronic noise exposure which can lead to decreased hearing sensitivity and the appearance of tinnitus. ${ }^{4,5}$

Tinnitus can have a significant negative impact on the quality of life of the sufferer. ${ }^{6,7}$ The severity of tinnitus can be affected due to the use of earphones. Excessive patterns of earphone use can increase the severity of tinnitus felt by tinnitus sufferers. This is due to the increased noise exposure received by tinnitus sufferers. ${ }^{8-10}$ The pain level due to tinnitus noise felt by the patient can be measured by Visual Analog Scale which is then divided into 5 degrees: no pain, mild pain, moderate pain, severe pain, and very severe pain. Then, the tinnitus severity level can be measured using the Tinnitus Handicap Inventory Questionnaire which can classify tinnitus into 5 grades of severitybased on the negative impact of tinnitus in the patient's life, very mild or no disability, mild, moderate, severe and very severe. ${ }^{11}$

The phenomenon of the widespread use of earphones in adolescents in Indonesia stimulated the researchers to find out the patterns of earphone use in young population and their correlation with the incidence of tinnitus. Also, this study was considered very important because tinnitus is a sign of decreased hearing function and could cause a decrease in cognitive performance. If a medical student is found to have decreased hearing function or a decrease in cognitive performance, the teaching and learning process could be disrupted which can lead to a decline inthe quality of medical students who are the successors of Indonesian medical personnel in the future.

In this study, the researchers wanted to find out the pattern of earphone use and its correlation with the tinnitus incidence rate and tinnitus severity as measured by the Visual Analog Scale and Tinnitus Handicap Inventory Questionnaire among students of the Faculty of Medicine, University of North Sumatra, class 2017-2019 using a crosssectional design. 


\section{METHOD}

This was an analytical study using acrosssectional design. The population in this study was all students of the Faculty of Medicine, University of North Sumatra, class 2017-2019 who used earphones. Total research sample were 160 participants, but thosewho met the inclusion and exclusion criteria through a questionnaire using a consecutive sampling technique were 148 participants.

The research was conducted for 3 months which was divided into two stages, namely, the first stage was filling out the Earphone Usage Pattern Questionnaire and the Tinnitus Questionnaire, then the results of the Tinnitus Questionnaire were examined and all research subjects suspected of having tinnitus were re-recorded.

In the second stage, research subjects who were suspected of having tinnitus and had previously recorded data were asked to continue filling out the Tinnitus Handicap Inventory Questionnaire and Visual Analog Scale Questionnaires, then analyzed the univariate and bivariate data. Univariate analysis was presented in tabular form by displaying the frequency distribution so that a descriptive picture of all the variables contained in the study could be seen. The bivariate analysis used was Chi-Square. Based on the results of statistical calculations, it can be seen the significance in the second stage, research subjects who were suspected of having tinnitus and had previously recorded data were asked to continue filling out the Tinnitus Handicap Inventory Questionnaire and Visual Analog Scale Questionnaires, then analyzed the univariate and bivariate data. Univariate analysis is presented in tabular form by displaying the frequency distribution, so that a descriptive picture of all the variables contained in the study could be seen. The bivariate analysis used was Chi-Square. Based on the results of statistical calculations, it could be seen the significance correlation between variables based on probability. The significance of 0.05 has a chance of being correct by $95 \%$ and for being wrong by $5 \%$. If the significance level is 0.05 , the confidence level is $95 \%$.

\section{RESULT}

In this study, it was found that the respondents who used earphones with a length of use $0-3$ years were 51 participants $(34.5 \%)$, while respondents with a length of use $>3$ years were 97 participants (65.5\%). Respondents who used earphones with a duration of use $<1$ hour totaled 57 participants $(38.5 \%)$, duration of use 1-2 hours totaled 55 participants $(37.2 \%)$, and duration of use 2-4 hours totaled 36 participants $(24.3 \%)$. Respondents who used earphones with a frequency of use 1-2 days were 35 participants $(23.6 \%)$, the frequency of use for 3-4 days was 60 participants $(40.5 \%)$, the frequency of use for 5-6 days was 27 participants (18.2\%), and the frequency of use every day amounted to 26 persons $(17.6 \%)$. Respondents who used earphones with a volume of use $<60 \%$ were 53 participants $(35.8 \%)$, a volume of use of $60-80 \%$ was 80 participants $(54.1 \%)$, and a volume of use $>80 \%$ was 15 persons $(10.1 \%)$.

Respondents with a pattern of using earphones with no risk were 53 participants (35.8\%) and respondents with a pattern of using earphones at risk were 95 participants $(64.2 \%)$.

Table 1. Description of the distribution of earphones usage patterns among students of the Faculty of Medicine, University of North Sumatra, Class of 2017-2019

\begin{tabular}{llll}
\hline & f & \% \\
\hline \multirow{2}{*}{ Length of use } & $0-3$ year & 51 & 34.5 \\
& $>3$ year & 97 & 65.5
\end{tabular}




\begin{tabular}{llll}
\multirow{4}{*}{ Duration of use } & $<1$ hour & 57 & 38.5 \\
& $1-2$ hour & 55 & 37.2 \\
Frequency of use & $2-4$ hour & 36 & 24.3 \\
& $1-2$ day & 35 & 23.6 \\
& $3-4$ day & 60 & 40.5 \\
Volume & $5-6$ day & 27 & 18.2 \\
& Every day & 26 & 17.6 \\
Pattern of use & $<60 \%$ & 53 & 35.8 \\
& $60-80 \%$ & 80 & 54.1 \\
& $>80 \%$ & 15 & 10.1 \\
& No risk & 53 & 35.8 \\
\hline
\end{tabular}

Table 2. Description of tinnitus distribution among students of the Faculty of Medicine, University of North Sumatra, Class of 2017-2019

\begin{tabular}{llll}
\hline & & f & \% \\
\hline $\begin{array}{l}\text { Incidence rate of } \\
\text { tinnitus }\end{array}$ & No & 96 & 64.9 \\
& Yes & 52 & 35.1 \\
\hline
\end{tabular}

Table 3. The correlation between earphone usagepatterns and the incidence rate of tinnitus among students of the Faculty of Medicine, University of North Sumatra, Class of 2017-2019

\begin{tabular}{|c|c|c|c|c|c|c|c|}
\hline \multirow[t]{3}{*}{$\begin{array}{c}\text { The pattern of use of } \\
\text { Earphone }\end{array}$} & \multicolumn{4}{|c|}{$\begin{array}{c}\text { Incidence rate of tinnitus } \\
\text { Total } \\
\text { P-value }\end{array}$} & \multirow[b]{3}{*}{ f } & \multirow[b]{3}{*}{$\%$} & \\
\hline & \multicolumn{2}{|c|}{ No } & \multicolumn{2}{|c|}{ Yes } & & & \\
\hline & f & $\%$ & f & $\%$ & & & \\
\hline No Risk & 41 & 27.8 & 12 & 8.1 & 53 & 35.9 & \\
\hline At Risk & 55 & 37.1 & 40 & 27 & 95 & 64.1 & 0.017 \\
\hline Total & 96 & 64.9 & 52 & 35.1 & 148 & 100 & \\
\hline
\end{tabular}

Table 2 showed respondents suspected of having tinnitus symptoms. The table showed 52 participants $(35.1 \%)$ from a total of 148 respondents.

In this study, it was known that the ratio of the number of respondents who experienced tinnitus with a pattern of using earphones at risk $(27 \%)$ is greater than that of respondentswith a pattern of using earphones without risk(8.1\%). The results of statistical tests showed that there was a significant difference between the pattern of using risky and non-risk earphones with the incidence of tinnitus and the $p$-value $=0.017(p<0.05)$ so there was a significant relationship between earphone use patterns and the incidence of tinnitus.

Based on the Tinnitus Questionnaire, 52 respondents were suspected of having tinnitus. Respondents suspected of having tinnitus then asked to fill in the Visual Analog Scale (VAS) and the Tinnitus Handicap Inventory Questionnaire (THI-Q).

This study obtained the result of distribution of tinnitus severity as measured by the Visual Analog Scale (VAS), where 
there were no respondents who felt painless, 29 participants felt mild pain $(55.8 \%), 23$ participants felt moderate pain (44.2\%), and there were no respondents who felt severe and very severe pain.

This study also obtained a description of the distribution of tinnitus severity as measured by the Tinnitus Handicap Inventory Questionnaire at grade 1 (very mild) totaling 18 participants $(34.6 \%)$, at grade 2 (mild) totaling 28 participants $(53.8 \%)$, at grade 3 (moderate) totaling 6(11.5\%), and there were no respondents at grade 4 (severe) and grade 5 (very severe).

Table 4. Tinnitus severity as measured by Visual Analog Scale among students of Faculty of Medicine, University of North Sumatra, Class of 2017-2019

\begin{tabular}{llcc}
\hline & & $\mathbf{f}$ & $\mathbf{\%}$ \\
\hline Score Result Vi- & No pain & 0 & 0 \\
sual Analog Scale & Mild pain & 29 & 55.8 \\
(VAS) & Moderate pain & 23 & 44.2 \\
& Severe pain & 0 & 0 \\
& Very severe & & \\
& pain & 0 & 0 \\
\hline
\end{tabular}

Table 5. Tinnitus severity as measured by Tinnitus Handicap Inventory Questionnaire among students of the Faculty of Medicine, University of North Sumatra, Class of 2017-2019

\begin{tabular}{lccc}
\hline & & f & $\mathbf{\%}$ \\
\hline Score Result & Grade 1 & 18 & 34.6 \\
Tinnitus & Grade 2 & 28 & 53.8 \\
Handicap & Grade 3 & 6 & 11.5 \\
Inventory & Grade 4 & 0 & 0 \\
Questionnaire & Grade 5 & 0 & 0 \\
(THI-Q) & & & \\
\hline
\end{tabular}

\section{DISCUSSION}

Previous research conducted by Ilma ${ }^{12}$ showed that earphone users with a length of use $>3$ years were $114(49.8 \%)$ and a length of use $0-3$ years were $115(50.2 \%)$ subjects. These results supported the finding that earphone users at the Faculty of Medicine, University of North Sumatra with a length of use $>3$ years were higher than previous studies report, this was because many teenagers nowadays were already using earphones ever since junior high school.

Earlier study conducted by Shah et al. ${ }^{13}$ about the duration of use of earphone showed that only $5 \%$ of students had a duration of use $<1$ hour and average duration of use $>4$ hour. These results indicated the duration of use of earphone at the Faculty of Medicine, University of North Sumatra was better when compared to the earlier study. This could be due to the level of knowledge about the harm of using earphones, already concerned about the harms of using earphones on ear health, the understanding that noise induced hearing loss noise is irreversible, and levels of exposure to information about ear health in medical students.

In a prior study conducted by Fitri Sakinah ${ }^{14}$ regarding the frequency of earphone use, the result was that $78.9 \%$ of respondents used earphones 1-4 days/week and 21.1\% 
used ear phones $>5$ days/week. On the other hand, a research conducted by Silvestre et al. ${ }^{15}$ in 2013 showed that $74.43 \%$ of respondents used earphones $>5$ days/ week. This discrepancy could be caused by using the earphones not for a long period or continuously at a relatively low volume or intensity. Fitri Sakinah ${ }^{14}$ research, regarding the volume of earphone used, found that $77.3 \%$ of respondents used earphones with a dangerous volume. These results were also supported by other research conducted by Levey et al. ${ }^{16}$ which found that 189 students used earphones with an average level of $92.3 \mathrm{~dB}$ or equivalent to $60 \%$ of the total volume. The use of high volume earphones could occur because earphone users could not enjoy music in low volume so they chose to increase the music volume even though they knew about the harm of using high volume earphones.

In previous research conducted by Putri ${ }^{17}$ on earphone usage patterns, it was found that $61.7 \%$ of respondents were risky earphone users. This high-risk pattern of earphone use was caused by the length of time using earphones $>3$ years, the duration of earphone use $>1$ hour/day, the frequency of earphone use $>4$ days/week, and the volume of earphone use $>60 \%$. $^{17,18}$

These results were higher than previous studies conducted by Sunny et al. ${ }^{19}$ which stated that tinnitus occurred $10.33 \%$ in global prevalence. The results obtained in our study were considered higher than those of Nondahl et al. ${ }^{6}$ and colleagues with the results of $10.6 \%$ of respondents suffering from tinnitus. A higher number of tinnitus sufferers compared to earlier studies could occur due to the prevalence of tinnitus which was high in adolescents $(0.6-49.25 \%)$, this increase could also occur because in adolescents there are cognitive and hormonal changes that could cause tinnitus reactions, and could be accompanied by anxiety or depression..$^{20-22}$

The results of the chi-square statistical test in our study were in line with the research conducted by Silvestre et al. ${ }^{18}$ in the year 2016 at Curitiba, Brazil which stated that there was a correlation between earphone usage patterns and the incidence rate of tinnitus ( $p$ $<0.05$ ). The habit of using earphones could cause tinnitus, although it occured when a person use it for more than three years, use it several times a week, use it for a long time in one day, and use it at high volume.

The results of measuring tinnitus severity using the Visual Analog Scale in this study were similar to previous studies conducted by Figueiredo et al. ${ }^{11}$ which found $0 \%$ with no pain results, $13 \%$ mild pain, $32.6 \%$ moderate pain, $37 \%$ severe pain, and $17.4 \%$ very severe pain. In our study there was no subject that was in severe pain and very severe pain. This finding could be due to differences in age, in line with previous studies where tinnitus severity was directly proportional to age. ${ }^{9}$

The results of measuring tinnitus severity using the Tinnitus Handicap Inventory Questionnaire in this study were likely to be similar with the result obtained by Al-Swiahb et al. ${ }^{23}$ which reported the distribution of very mild (13,75\%), mild (32.5\%), and moderate $(37.5 \%)$. In this study, it could be seen that there was a correlation between the VAS and THI scores. This result was in accordance with the finding of Figueiredo et al. ${ }^{11}$

Based on the results of this study, to prevent the occurrence of tinnitus the researchers suggest that students of the Faculty of Medicine, University of North Sumatra reduce the duration of earphone use to $<1$ hour/day, the frequency of earphone use to $<5$ days/week, and the volume of earphone use $<60 \%$ each time using earphones.

The researchers suggest further research in tinnitus using audiometric examinations to simultaneously determine whether hearing loss is present due to the risky pattern of earphone use.

It is also necessary to do further research on the components of the earphone usage pattern, such as the type of earphone used and 
the type of music being listened to.

Furthermore, the researchers proposed another research with linear regression method to determine the extent of duration, frequency and volume of the earphone usage pattern criteria in relation with the tinnitus incidence rate.

\section{REFERENCE}

1. Hadinoto SO. Gambaran Pengetahuan, Sikap Dan Perilaku Remaja Tentang Gangguan Pendengaran Akibat Penggunaan Piranti Dengar. J Chem InfModel. 2014; 53 : 1689-99.

2. Kim MG, Hong SM, Shim HJ, Kim YD, Cha CII, Yeo SG. Hearing threshold of Korean adolescents associated with the use of personal music players. Yonsei Med J. 2009; 50: 771-6.

3. Pellegrino E, Lorini C, Allodi G, Buonamici C, Garofalo G, Bonaccorsu G. Musiclistening Habits with MP3 Player in a Group of Adolescents: a descriptive survey. Ann Ig. 2013; 25: 367-76.

4. Dobie RA. Prevention of Noise-Induced Hearing Loss. Arch Otolaryngol Head Neck Surg. 1995; 121: 385-91.

5. Arlinger S. Negative Consequences of Uncorrected Hearing Loss. Int J Audiol. 2003; 42: 2817-20.

6. Nondahl DM, Cruickshanks KJ, Huang GH, Klein BEK, Klein R, Nieto FJ, et al. Tinnitus and its risk factors in the Beaver Dam Offspring Study. Int J Audiol. 2011; 50: 313-20.

7. Alhazmi F, Kay T, Mackenzie I, Kemp GJ, Sluming V. An Investigation of the Impact of Tinnitus Perception on the Quality of Life. J Phonetics Audiol. 2016; 2 (1): 1-7.

8. Mazurek B, Olze H, Haupt H, Szczepek AJ. The more the worse: The grade of noiseinduced hearing loss associates with the severity of tinnitus. Int J Environ Res Public Health. 2010; 7: 3071-9.

9. Park B, Choi HG, Lee HJ, An SY, Kim SW, Lee JS, et al. Analysis of the prevalence of and risk factors for tinnitus in a young population. Otol Neurotol. 2014; 35 (7): 1218-22.

10. Kurniawati SP. Intensitas Kebisingan Terhadap Gangguan Pendengaran dan Keluhan Tinnitus pada Pekerja Penggilingan Daging di Kabupaten Jember. Epub ahead of print. 2017. DOI: $10.1242 /$ jcs. 150862 .

11. Figueiredo RR, De Azevedo AA, Oliveira PDM. Correlation Analysis of the VisualAnalogue Scale and the Tinnitus Handicap Inventory in Tinnitus Patients. Braz $\mathbf{J}$ Otorhinolaryngol. 2009; 75 (1): 76-9.

12. Ilma ZD. Peranti Dengar di SMAN X Tangerang Selatan tahun 2016. Fak Kedokt Univ Islam Negeri Syarif Hidayatullah Jakarta.

13. Shah S, Gopal B, Reis J, Novak M. Hear Today, Gone Tomorrow: an assessment of portable entertainment player use and hearing acuity in a community sample. J Am Board Fam Med. 2009; 22 (1): 17-23.

14. Sakinah F. Hubungan Kekerapan, Durasi dan Intensitas Penggunaan Earphone Telepon Genggam dengan Kejadian Tinnitus Subjektif pada Mahasiswa Profesi Dokter Angkatan 2014. Universitas Andalas, 2017.

15. Silvestre RAA, Ribas A, Marques JM, de Lacerda ABM. Tinnitus in adolescents and its relation to the use of personal sound systems. Int Tinnitus J. 2013; 18 (2): 138-142.

16. Levey S, Fligor BJ, Ginocchi C, Kagimbi L. The Effects of Noise-Induced Hearing Loss on Children and Young Adults. Contemp Issues Commun Sci Disord. 2012; 39: 76-83.

17. Putri FM. Hubungan Penggunaan Peranti Dengar terhadap Fungsi Pendengaran Pada Siswa SMA X Di Tangerang Selatan (Skripsi). 2016.

18. Silvestre RAA, Ribas Â, Hammerschmidt $\mathrm{R}$, de Lacerda ABM. High-frequency profile in adolescents and its. J Pediatr (Rio J). Epub ahead of print. 2016. DOI: 10.1016/j. jped.2015.07.008.

19. Sunny OD, Nkiruka AC, Abayomi SO. Subjective tinnitus and its association with use of ear phones among students of the college of medicine, university of Lagos, Nigeria. Int Tinnitus J. 2012; 17: 169-172.

20. Gilles A, Hal G Van, Ridder D De, Wouters K, de Heyning PV. Epidemiology of Noise- 
Induced Tinnitus and the Attitudes and Beliefs Epidemiology of Noise-Induced Tinnitus and the Attitudes and Beliefs towards Noise and Hearing Protection in Adolescents. Epub ahead of print. 2013; 8 (7). DOI: 10.1371/journal.pone.0070297.

21. Rosing SN, Schmidt JH, Wedderkopp N, Baguley DM. Prevalence of tinnitus and hyperacusis in children and adolescents : a systematic review. Epub ahead of print. 2016; 1-30. DOI:10.1136/bmjopen-2015-010596.

22. Fligor B. Audiological evaluation and management of teenagers with tinnitus. ent Audiol news. 2017; 25 (8).

23. Al-Swiahb J, Park SN. Characterization of tinnitus in different age groups: A retrospective review. Noise Health .2016; 18 (83): 214-9. 